Full Length Article

\title{
Ammonia oxidation at high pressure and intermediate temperatures
}

\author{
Yu Song a,b ${ }^{\mathrm{a}}$, Hamid Hashemi ${ }^{\mathrm{a}}$, Jakob Munkholt Christensen ${ }^{\mathrm{a}}$, Chun Zou ${ }^{\mathrm{b}}$, Paul Marshall ${ }^{\mathrm{c}}$, \\ Peter Glarborg ${ }^{\mathrm{a}, *}$
}

${ }^{a}$ Department of Chemical and Biochemical Engineering, Technical University of Denmark, DK-2800 Kgs. Lyngby, Denmark

${ }^{\mathrm{b}}$ State Key Laboratory of Coal Combustion, Huazhong University of Science and Technology, Wuhan 430074, China

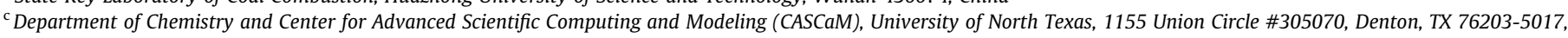
United States

\section{A R T I C L E I N F O}

\section{Article history:}

Received 11 January 2016

Received in revised form 9 March 2016

Accepted 21 April 2016

Available online 10 May 2016

\section{Keywords}

$\mathrm{NH}_{3}$ oxidation

High pressure

Flow reactor

$\mathrm{H}_{2} \mathrm{NO}+\mathrm{O}_{2}$ rate constant

Kinetic model

\begin{abstract}
A B S T R A C T
Ammonia oxidation experiments were conducted at high pressure (30 bar and 100 bar) under oxidizing and stoichiometric conditions, respectively, and temperatures ranging from 450 to $925 \mathrm{~K}$. The oxidation of ammonia was slow under stoichiometric conditions in the temperature range investigated. Under oxidizing conditions the onset temperature for reaction was $850-875 \mathrm{~K}$ at $30 \mathrm{bar}$, while at 100 bar it was about $800 \mathrm{~K}$, with complete consumption of $\mathrm{NH}_{3}$ at $875 \mathrm{~K}$. The products of reaction were $\mathrm{N}_{2}$ and $\mathrm{N}_{2} \mathrm{O}$, while $\mathrm{NO}$ and $\mathrm{NO}_{2}$ concentrations were below the detection limit even under oxidizing conditions. The data were interpreted in terms of a detailed chemical kinetic model. The rate constant for the reaction of the important intermediate $\mathrm{H}_{2} \mathrm{NO}$ with $\mathrm{O}_{2}$ was determined from ab initio calculations to be $2.3 \times 10^{2} \mathrm{~T}^{2.994} \exp (-9510 \mathrm{~K} / \mathrm{T}) \mathrm{cm}^{3} \mathrm{~mol}^{-1} \mathrm{~s}^{-1}$. The agreement between experimental results and model work was satisfactory. The main oxidation path for $\mathrm{NH}_{3}$ at high pressure under oxidizing conditions is $\mathrm{NH}_{3} \stackrel{+\mathrm{OH}}{\longrightarrow} \mathrm{NH}_{2} \stackrel{+\mathrm{HO}_{2}, \mathrm{NO}_{2}}{\longrightarrow} \mathrm{H}_{2} \mathrm{NO} \stackrel{+\mathrm{O}_{2}}{\longrightarrow} \mathrm{HNO} \stackrel{+\mathrm{O}_{2}}{\longrightarrow} \mathrm{NO} \stackrel{+\mathrm{NH}_{2}}{\longrightarrow} \mathrm{N}_{2}$. The modeling predictions are most sensitive to the reactions $\mathrm{NH}_{2}+\mathrm{NO}=\mathrm{NNH}+\mathrm{OH}$ and $\mathrm{NH}_{2}+\mathrm{HO}_{2}=\mathrm{H}_{2} \mathrm{NO}+\mathrm{OH}$, which promote the ammonia consumption by forming $\mathrm{OH}$ radicals, and to $\mathrm{NH}_{2}+\mathrm{NO}=\mathrm{N}_{2}+\mathrm{H}_{2} \mathrm{O}$ and $\mathrm{NH}_{2}+\mathrm{NO}_{2}=\mathrm{N}_{2} \mathrm{O}+\mathrm{H}_{2} \mathrm{O}$, which are the main chain-terminating steps.
\end{abstract}

(C) 2016 Elsevier Ltd. All rights reserved.

\section{Introduction}

Ammonia is an important combustion intermediate in formation of nitric oxide from nitrogen organically bound in fuels. For most solid fuels, $\mathrm{NH}_{3}$ is formed directly during devolatilization [1], and it has also been reported as a product of gasification [2]. The selectivity for forming $\mathrm{NO}$ or $\mathrm{N}_{2}$ from $\mathrm{N}$-volatiles in combustion depends largely on the fate of amine radicals such as $\mathrm{NH}_{2}$, $\mathrm{NH}$, and $\mathrm{N}[1,3]$. Ammonia is also known as an efficient additive for Selective Non-Catalytic Reduction of NO (SNCR) [3,4]. Recently, ammonia has attracted interest as a potential carbon-free energy carrier [5]. Results on oxidation of $\mathrm{NH}_{3}$ are available from flames [6-16], shock tubes [17-27], and flow reactors [2,28-30]. In addition, a number of modeling studies and reviews of ammonia chemistry have been reported $[3,27,28,31-35]$. Supplementing the oxidation studies, extensive work has been conducted on the kinetics of the SNCR process [3,4,36-38].

\footnotetext{
* Corresponding author.

E-mail address: pgl@kt.dtu.dk (P. Glarborg).
}

With the interest in amine-based fuels as energy carriers [39], reliable experimental data for oxidation of ammonia at high pressure become important. High-temperature results at increased pressure are available from recent work in shock tubes and premixed flames. Mathieu and Petersen [27] measured the ignition time for ammonia diluted in $\mathrm{Ar}$ at $1.4,11$, and 30 bar, respectively, while Hayakawa et al. [15] determined the burning velocity of ammonia/air mixtures at pressures of 1-5 bar. However, studies of ammonia oxidation at low-to-medium temperatures and high pressure are scarce.

The purpose of the present study is to investigate ammonia oxidation at high pressure (30-100 bar) and temperatures up to $925 \mathrm{~K}$. Experiments are conducted with stoichiometric and lean $\mathrm{NH}_{3} / \mathrm{O}_{2}$ mixtures, highly diluted in $\mathrm{N}_{2}$, in a laminar flow reactor. The results are interpreted in terms of a detailed chemical kinetic model for ammonia oxidation. The reaction mechanism, which is based on earlier work on nitrogen chemistry $[34,38,40,41]$, is updated in the present work, emphasizing reactions important at high pressure. Under the present conditions, the nitroxide radical $\mathrm{H}_{2} \mathrm{NO}$ is an important intermediate, and the rate constant for the 
reaction between $\mathrm{H}_{2} \mathrm{NO}$ and $\mathrm{O}_{2}$ has been derived from ab initio calculations.

\section{Experimental}

The experimental setup was a laboratory-scale high-pressure laminar flow reactor designed to approximate plug flow. The setup is described in detail elsewhere [42] and only a brief description is provided here. The system was used here for investigation of ammonia oxidation at 30 bar and 100 bar pressure, respectively, and temperatures from 450 to $925 \mathrm{~K}$. The reactant gases were premixed before entering the reactor. The reactions took place in a tube under laminar flow conditions. The tube was made of quartz (inner diameter of $7.5 \mathrm{~mm}$ ) or alumina (Degussit AL23, inner diameter $6 \mathrm{~mm}$ ). The temperature profile in the flow reactor was measured by a thermocouple positioned in the void between the quartz reactor and the steel shell. Results for 100 bar are shown in Fig. 1 while the 30 bar profiles are available as supplementary material. An isothermal reaction zone of $39-47 \mathrm{~cm}$ was achieved in the reactor. All gases used in the present experiments were high purity gases or mixtures with certified concentrations. The total flow rate was $2.8 \mathrm{~L} \mathrm{~min}^{-1}$ (STP). The product analysis was conducted with an on-line 6890N Agilent Gas Chromatograph (GCTCD/FID from Agilent Technologies) and an AO2020 $\mathrm{NH}_{3} / \mathrm{NO} / \mathrm{NO}_{2}$ analyser from $A B B$. The relative measurement uncertainties for the species detected were in the range $\pm 2-6 \%$.

\section{Chemical kinetic model}

The starting mechanism and corresponding thermodynamic properties were drawn from the recent work by Klippenstein et al. [38]. The mechanism was carefully updated, emphasizing reactions of importance under the conditions of the present study. Table 1 lists the key reactions in the $\mathrm{NH}_{3}$ oxidation scheme with the rate coefficients used in the present work. The full mechanism is available as supplemental material.

At the high-pressure medium-temperature conditions of this work, ammonia oxidation occurs to a significant extent through the $\mathrm{H}_{2} \mathrm{NO}$ intermediate. Rate constants for $\mathrm{H}_{2} \mathrm{NO}$ reactions are generally quite uncertain. In the present work, we characterize the key reaction of $\mathrm{H}_{2} \mathrm{NO}$ with $\mathrm{O}_{2}$ by ab initio calculations, as described below.

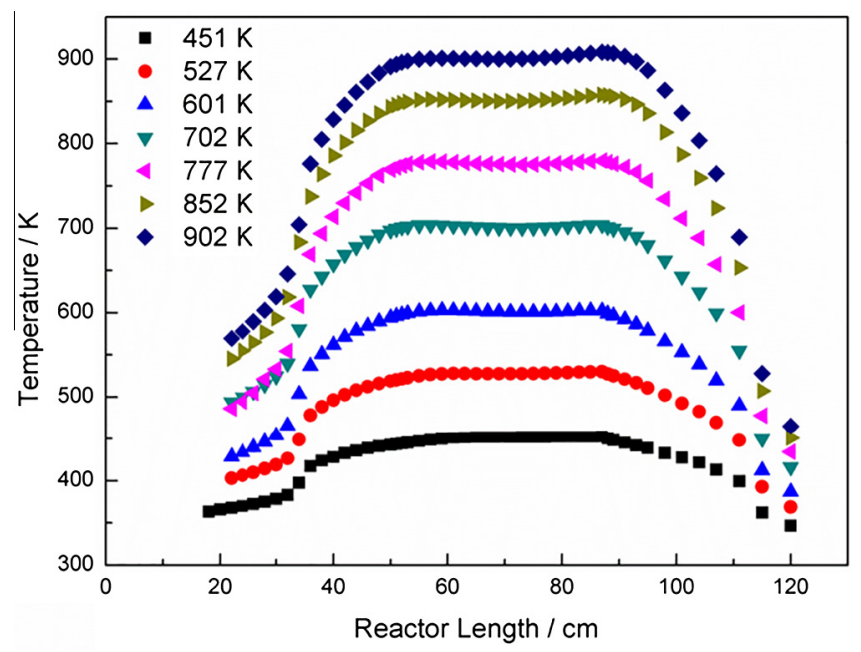

Fig. 1. Measured temperature profiles along the reactor axis for 100 bar conditions
Table 1

Selected reactions from the $\mathrm{NH}_{3}$ subset. Parameters for use in the modified Arrhenius expression $\mathrm{k}=\mathrm{AT}^{\beta} \exp (-\mathrm{E} /[\mathrm{RT}])$. Units are mol, cm, s, cal

\begin{tabular}{|c|c|c|c|c|c|}
\hline & & A & $\beta$ & $\mathrm{E}$ & Source \\
\hline \multirow[t]{3}{*}{1} & $\mathrm{NH}_{2}+\mathrm{H}(+\mathrm{M}) \rightleftharpoons \mathrm{NH}_{3}(+\mathrm{M})$ & $1.6 \mathrm{E} 14$ & 0.000 & 0 & [43] \\
\hline & Low pressure limit: & $3.6 \mathrm{E} 22$ & -1.760 & 0 & \\
\hline & \multicolumn{5}{|c|}{ Troe parameters: 0.5 1.0E-30 1.0E30 } \\
\hline 2 & $\mathrm{NH}_{3}+\mathrm{H} \rightleftharpoons \mathrm{NH}_{2}+\mathrm{H}_{2}$ & $6.4 \mathrm{E} 05$ & 2.390 & 10,171 & {$[44]$} \\
\hline 3 & $\mathrm{NH}_{3}+\mathrm{O} \rightleftharpoons \mathrm{NH}_{2}+\mathrm{OH}$ & $9.4 \mathrm{E} 06$ & 1.940 & 6460 & [45] \\
\hline 4 & $\mathrm{NH}_{3}+\mathrm{OH} \rightleftharpoons \mathrm{NH}_{2}+\mathrm{H}_{2} \mathrm{O}$ & 2.0E06 & 2.040 & 566 & [46] \\
\hline 5 & $\mathrm{NH}_{3}+\mathrm{HO}_{2} \rightleftharpoons \mathrm{NH}_{2}+\mathrm{H}_{2} \mathrm{O}_{2}$ & 3.0E11 & 0.000 & 22,000 & [3] est \\
\hline 6 & $\mathrm{NH}_{2}+\mathrm{HO}_{2} \rightleftharpoons \mathrm{NH}_{3}+\mathrm{O}_{2}$ & 1.7E04 & 1.550 & 2027 & {$[47]^{\mathrm{a}}$} \\
\hline 7 & $\mathrm{NH}_{2}+\mathrm{H} \rightleftharpoons \mathrm{NH}_{2}+\mathrm{H}_{2}$ & 7.2E05 & 2.320 & 799 & [48] \\
\hline 8 & $\mathrm{NH}_{2}+\mathrm{O} \rightleftharpoons \mathrm{HNO}+\mathrm{H}$ & $6.6 \mathrm{E} 13$ & 0.000 & 0 & $\begin{array}{l}\text { See } \\
{[41]}\end{array}$ \\
\hline \multirow[t]{2}{*}{9} & \multirow[t]{2}{*}{$\mathrm{NH}_{2}+\mathrm{O} \rightleftharpoons \mathrm{NH}+\mathrm{OH}$} & 7.0E12 & 0.000 & 0 & $\begin{array}{l}\text { See } \\
{[41]}\end{array}$ \\
\hline & & $8.6 \mathrm{E}-1$ & 4.010 & 1673 & \\
\hline 10 & $\mathrm{NH}_{2}+\mathrm{OH} \rightleftharpoons \mathrm{NH}+\mathrm{H}_{2} \mathrm{O}$ & 3.3E06 & 1.949 & -217 & {$[38,49]$} \\
\hline 11 & $\mathrm{NH} 2+\mathrm{HO}_{2} \rightleftharpoons \mathrm{H}_{2} \mathrm{NO}+\mathrm{OH}$ & $5.0 \mathrm{E} 13$ & 0.000 & 0 & $\begin{array}{l}\text { See } \\
\text { text }\end{array}$ \\
\hline \multirow[t]{2}{*}{12} & \multirow[t]{2}{*}{$\mathrm{NH}_{2}+\mathrm{HO}_{2} \rightleftharpoons \mathrm{HNO}+\mathrm{H}_{2} \mathrm{O}$} & $1.6 \mathrm{E} 07$ & 0.550 & 525 & {$[47]^{\mathrm{a}, \mathrm{b}}$} \\
\hline & & 5.7E15 & -1.120 & 707 & \\
\hline 13 & $\mathrm{NH}_{2}+\mathrm{HO}_{2} \rightleftharpoons \mathrm{HON}+\mathrm{H}_{2} \mathrm{O}$ & $2.1 \mathrm{E} 07$ & 0.640 & 811 & {$[47]^{\mathrm{a}}$} \\
\hline 14 & $\mathrm{NH}_{2}+\mathrm{O}_{2} \rightleftharpoons \mathrm{H}_{2} \mathrm{NO}+\mathrm{O}$ & $2.6 \mathrm{E} 11$ & 0.487 & 29,050 & [38] \\
\hline 15 & $\mathrm{NH}_{2}+\mathrm{O}_{2} \rightleftharpoons \mathrm{HNO}+\mathrm{OH}$ & $2.9 \mathrm{E}-2$ & 3.764 & 18,185 & [38] \\
\hline 16 & $\mathrm{NH}_{2}+\mathrm{NH}_{2} \rightleftharpoons \mathrm{NH}_{3}+\mathrm{NH}$ & $5.6 \mathrm{E} 00$ & 3.530 & 552 & [49] \\
\hline 17 & $\mathrm{NH}_{2}+\mathrm{HNO} \rightleftharpoons \mathrm{NH}_{3}+\mathrm{NO}$ & 3.6E06 & 1.630 & -1250 & [50] \\
\hline \multirow[t]{2}{*}{18} & \multirow[t]{2}{*}{$\mathrm{NH}_{2}+\mathrm{NO} \rightleftharpoons \mathrm{N}_{2}+\mathrm{H}_{2} \mathrm{O}$} & $1.3 \mathrm{E} 16$ & -1.25 & 0 & [38] \\
\hline & & $-3.1 \mathrm{E} 13$ & -0.48 & 1180 & \\
\hline 19 & $\mathrm{NH}_{2}+\mathrm{NO} \rightleftharpoons \mathrm{NNH}+\mathrm{OH}$ & $3.1 \mathrm{E} 13$ & -0.48 & 1180 & [38] \\
\hline 20 & $\mathrm{NH}_{2}+\mathrm{NO}_{2} \rightleftharpoons \mathrm{N}_{2} \mathrm{O}+\mathrm{H}_{2} \mathrm{O}$ & $2.6 \mathrm{E} 18$ & -2.191 & 455 & [51] \\
\hline 21 & $\mathrm{NH}_{2}+\mathrm{NO}_{2} \rightleftharpoons \mathrm{H}_{2} \mathrm{NO}+\mathrm{NO}$ & $9.1 \mathrm{E} 11$ & 0.032 & -1512 & [51] \\
\hline 22 & $\mathrm{NH}_{2}+\mathrm{HONO} \rightleftharpoons \mathrm{NH}_{3}+\mathrm{NO}_{2}$ & 7.1E01 & 3.020 & -4940 & [50] \\
\hline 23 & $\mathrm{H}_{2} \mathrm{NO}+\mathrm{M} \rightleftharpoons \mathrm{HNO}+\mathrm{H}+\mathrm{M}$ & $2.8 \mathrm{E} 24$ & -2.830 & 64,915 & [33] \\
\hline 24 & $\mathrm{H}_{2} \mathrm{NO}+\mathrm{H} \rightleftharpoons \mathrm{HNO}+\mathrm{H}_{2}$ & 3.0E07 & 2.000 & 2000 & [36] est \\
\hline 25 & $\mathrm{H}_{2} \mathrm{NO}+\mathrm{H} \rightleftharpoons \mathrm{NH}_{2}+\mathrm{OH}$ & $5.0 \mathrm{E} 13$ & 0.000 & 0 & [36] est \\
\hline 26 & $\mathrm{H}_{2} \mathrm{NO}+\mathrm{O} \rightleftharpoons \mathrm{HNO}+\mathrm{OH}$ & $3.0 \mathrm{E} 07$ & 2.000 & 2000 & [36] est \\
\hline 27 & $\mathrm{H}_{2} \mathrm{NO}+\mathrm{OH} \rightleftharpoons \mathrm{HNO}+\mathrm{H}_{2} \mathrm{O}$ & $1.0 \mathrm{E} 14$ & 0.000 & 0 & [52] \\
\hline 28 & $\mathrm{H}_{2} \mathrm{NO}+\mathrm{HO}_{2} \rightleftharpoons \mathrm{HNO}+\mathrm{H}_{2} \mathrm{O}_{2}$ & 2.9E04 & 2.690 & -1600 & [33] \\
\hline 29 & $\mathrm{H}_{2} \mathrm{NO}+\mathrm{O}_{2} \rightleftharpoons \mathrm{HNO}+\mathrm{HO}_{2}$ & 2.3E02 & 2.994 & 18,900 & pw \\
\hline 30 & $\mathrm{H}_{2} \mathrm{NO}+\mathrm{NH}_{2} \rightleftharpoons \mathrm{HNO}+\mathrm{NH}_{3}$ & 3.0E12 & 0.000 & 1000 & [36] est \\
\hline 31 & $\mathrm{H}_{2} \mathrm{NO}+\mathrm{NO}_{2} \rightleftharpoons \mathrm{HONO}+\mathrm{HNO}$ & $6.0 \mathrm{E} 11$ & 0.000 & 2000 & [53] est \\
\hline 32 & $\mathrm{HNO}+\mathrm{O}_{2} \rightleftharpoons \mathrm{NO}+\mathrm{HO}_{2}$ & $2.0 \mathrm{E} 13$ & 0.000 & 16,000 & [33] \\
\hline 33 & $\mathrm{NNH} \rightleftharpoons \mathrm{N}_{2}+\mathrm{H}$ & 1.0E09 & 0.000 & 0 & [38] \\
\hline 34 & $\mathrm{NNH}+\mathrm{O}_{2} \rightleftharpoons \mathrm{N}_{2}+\mathrm{HO}_{2}$ & $5.6 \mathrm{E} 14$ & -0.385 & -13 & [38] \\
\hline
\end{tabular}

a Rate constant calculated for $1 \mathrm{~atm}$

b Duplicate reaction - the resulting rate constant is the sum of the two expressions.

\subsection{Ab initio calculations}

The nitroxide radical $\mathrm{H}_{2} \mathrm{NO}$, molecular oxygen and the transition state for their reaction were investigated computationally. First, geometries and frequencies (scaled by a standard factor of 0.954 [54]) were obtained with UQCISD $/ 6-311 \mathrm{G}(\mathrm{d}, \mathrm{p})$ theory, using spin-unrestricted wavefunctions as implemented within the Gaussian 09 code [55]. At these geometries (see Fig. 2), single-point energies were calculated at the $\operatorname{UCCSD}(T)$ level of theory with the aug-cc-pVTZ and aug-cc-pVQZ basis sets, using spin-restricted wavefunctions within the Molpro 2010 program [56], and extrapolated to the complete basis set limit for coupled cluster theory $(\operatorname{CCSD}(\mathrm{T}) / \mathrm{CBS})$. Corrections were added to this result based on UCCSD $(T) / c c-p w V T Z$ results obtained with core electrons included and excluded from the correlation treatment, and relativistic effects evaluated at the CISD/cc-pwVTZ level of theory. The results are summarized in the supplementary material. The rate constant was then derived via canonical transition state theory as implemented within the Multiwell program suite [57], with tunneling accounted for via the Eckart model.

Some of the prior studies of $\mathrm{H}_{2} \mathrm{NO}$ raised the issue of whether this molecule is planar or pyramidal $[58,59]$. Out-of-plane bending 

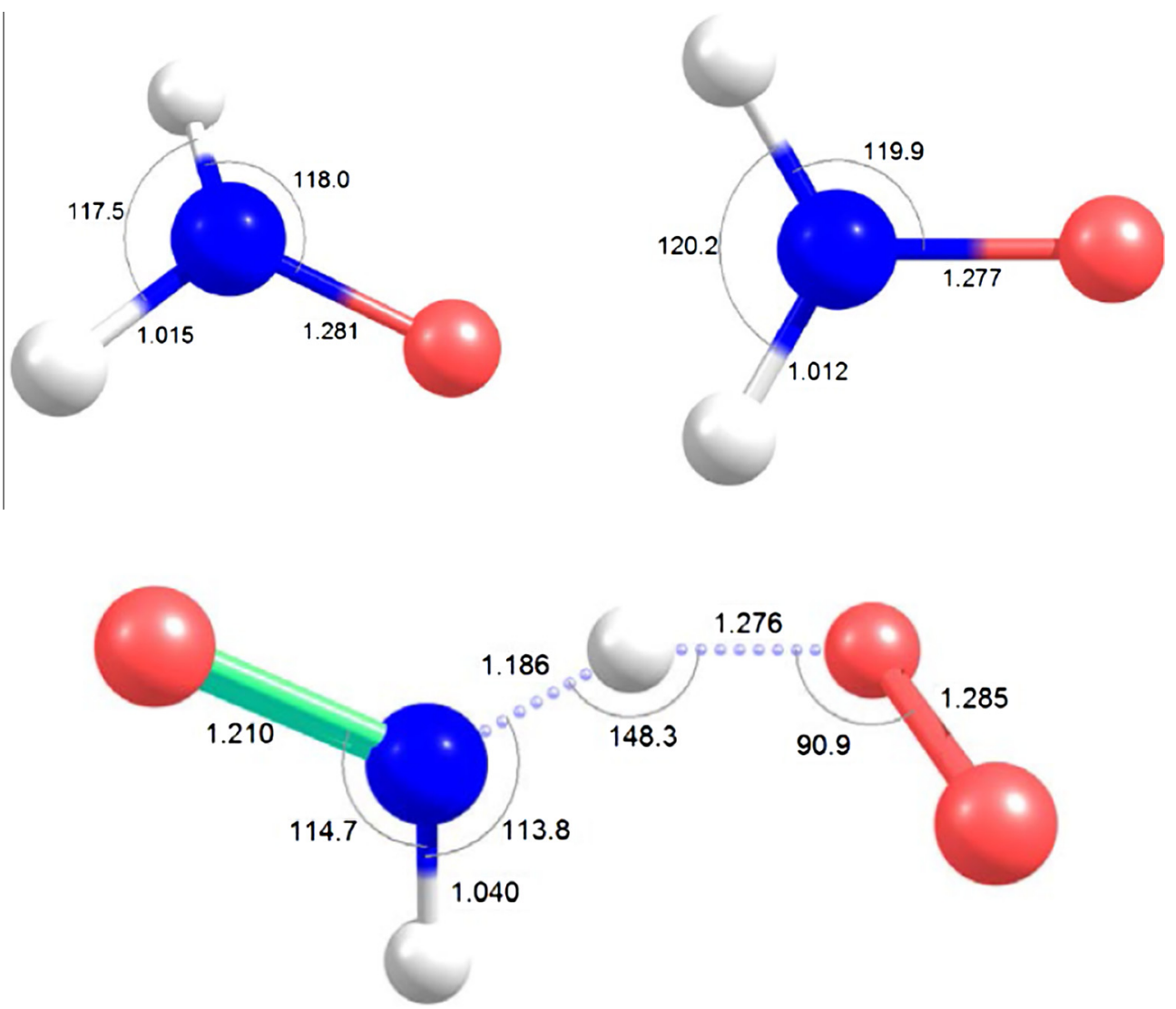

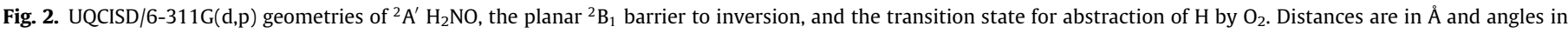
degrees. Dihedral angles in the TS: HNHO $-159.2^{\circ}, \mathrm{OHNH}-49.2^{\circ}, \mathrm{OOHN}-24.2^{\circ}$.

of the $\mathrm{C}_{2 \mathrm{v}}$ structure was explored via scans of the angle between the $\mathrm{O}-\mathrm{N}$ bond and the $\mathrm{NH}_{2}$ plane, with the rest of the geometry allowed to optimize. The results are plotted in Fig. 3 that shows a double well potential with a very small barrier of $17 \mathrm{~cm}^{-1}$ to inversion. The harmonic frequency evaluated at either minimum is $481 \mathrm{~cm}^{-1}$, but clearly the potential is significantly anharmonic.

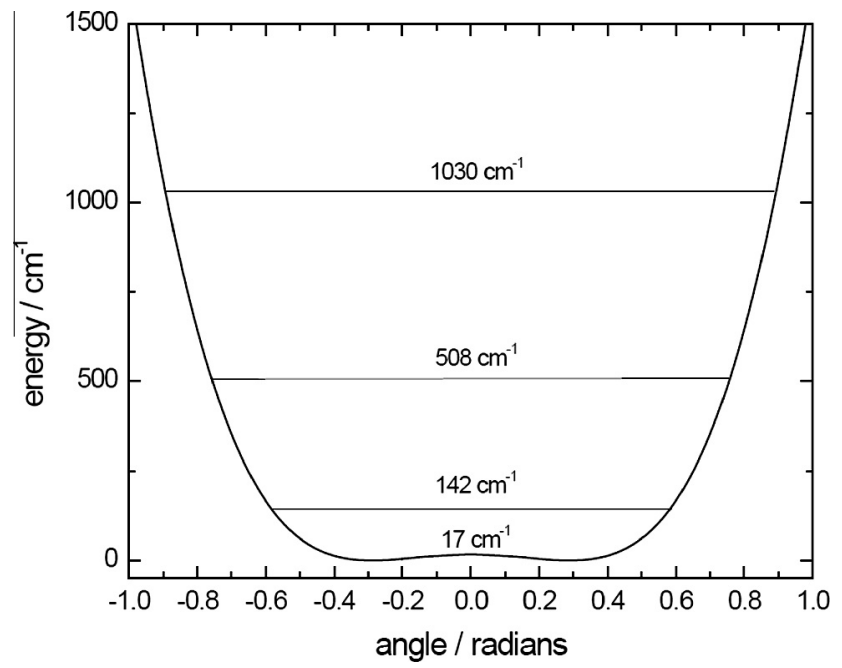

Fig. 3. The double-well potential of $\mathrm{H}_{2} \mathrm{NO}$ computed at the UQCISD/6-311G(d,p) level of theory. The barrier height and the first three eigenvalues for out-of-plane bending are relative to the minima. The angle is defined as the deviation from $180^{\circ}$ (the planar conformation) for the angle $\mathrm{O}-\mathrm{N}-\mathrm{X}$ where $\mathrm{X}$ is a point midway between the two $\mathrm{H}$ atoms.
The moment of inertia for bending was estimated to be $0.407 \mathrm{amu} \AA^{2}$, by treating the planar geometry like a three-atom linear molecule [60] with a mass of 2 amu at the midpoint of the two $\mathrm{H}$ atoms. The eigenvalues obtained via the FGH method [61] for quantized bending motion on this potential are summarized in the supplemental material; the first three are 142, 508 and $1030 \mathrm{~cm}^{-1}$ above the minima. Even the lowest level is well above the inversion barrier so $\mathrm{H}_{2} \mathrm{NO}$ explores both sides equally. Because the wavefunction for the ground state is maximized at the planar geometry, we use this structure and a symmetry number of 2 to calculate rotational partition functions. Vibrational partitions were based on the harmonic oscillator model for the remaining 5 modes of $\mathrm{H}_{2} \mathrm{NO}$ combined with results derived via a direct count for the out-of-plane bending energy levels. Together with the heat of formation at $298 \mathrm{~K}$ from the Active Thermochemical Tables [62], the thermochemistry is summarized within the NASA polynomial included in the supplemental information.

\subsection{Reaction mechanism}

The reactions of ammonia with the radical pool and $\mathrm{O}_{2}$ involve hydrogen abstraction to form $\mathrm{NH}_{2}$. The rate constants for these steps, taken from the mechanism of Klippenstein et al. [38], are mostly well established, but the values for $\mathrm{NH}_{3}+\mathrm{HO}_{2}$ (R4) (estimated [3]) and $\mathrm{NH}_{3}+\mathrm{O}_{2}$ (R5b) (ab initio calculation [47]) are more uncertain.

The oxidation rate for ammonia and the products of reaction are largely determined by the fate of $\mathrm{NH}_{2}$. The $\mathrm{NH}_{2}$ radical is mainly consumed by reaction with the $\mathrm{HO}_{2}$ radical (R5b, R11-R13), which builds up in considerable concentrations under the present conditions, and with the stable species $\mathrm{NO}(\mathrm{R} 18, \mathrm{R} 19)$ and $\mathrm{NO}_{2}(\mathrm{R} 20$, 
R21). The $\mathrm{NH}_{2}+\mathrm{HO}_{2}$ reaction has been studied theoretically by several groups $[33,47,63-65]$, while there are only indirect room temperature measurements available for the rate constant [6668]. It has a number of product channels and may occur both on the singlet and triplet surfaces. We choose to rely on the work of Sumathi and Peyerimhoff [47] who calculated rate constants for formation of the adduct $\mathrm{H}_{2} \mathrm{NOOH}$ and its isomers $\mathrm{HN}(\mathrm{OH}) \mathrm{OH}$ and $\mathrm{H}_{2} \mathrm{~N}(\mathrm{OH}) \mathrm{O}$, as well as the products $\mathrm{NH}_{3}+\mathrm{O}_{2}, \mathrm{NH}_{2} \mathrm{O}+\mathrm{OH}$, $\mathrm{HNO}+\mathrm{H}_{2} \mathrm{O}$, and $\mathrm{HON}+\mathrm{H}_{2} \mathrm{O}$. The predominant contribution to the total rate constant is predicted to be dissociation of energized $\mathrm{H}_{2}$ $\mathrm{NOOH}$ to $\mathrm{NH}_{2} \mathrm{O}+\mathrm{OH}$ over the temperature range $300-2000 \mathrm{~K}$ and pressures from 0.001 to $10 \mathrm{~atm}$. At pressures above $10 \mathrm{~atm}$, stabilisation of $\mathrm{H}_{2} \mathrm{NOOH}$ becomes important according to Sumathi and Peyerimhoff. However, little is known about the fate of the $\mathrm{H}_{2-}$ $\mathrm{NOOH}$ adduct. In the present work, we take $\mathrm{H}_{2} \mathrm{NO}+\mathrm{OH}(\mathrm{R} 11)$ to be the primary products of reaction and assume the rate constant to be equal to the high-pressure limit of the overall reaction, which we estimate to be $5 \times 10^{13} \mathrm{~cm}^{3} \mathrm{~mol}^{-1} \mathrm{~s}^{-1}$. This value is only slightly higher than the indirect measurement for $\mathrm{NH}_{2}+\mathrm{HO}_{2}$ by Lozovskii et al. [67] at 570 torr, but a factor of two higher than the calculation of Sumathi and Peyerimhoff.

The rate constants for the reactions of $\mathrm{NH}_{2}$ with $\mathrm{NO}$ and $\mathrm{NO}_{2}$,

$$
\begin{aligned}
& \mathrm{NH}_{2}+\mathrm{NO} \rightleftharpoons \mathrm{N}_{2}+\mathrm{H}_{2} \mathrm{O} \\
& \mathrm{NH}_{2}+\mathrm{NO} \rightleftharpoons \mathrm{NNH}+\mathrm{OH} \\
& \mathrm{NH}_{2}+\mathrm{NO}_{2} \rightleftharpoons \mathrm{N}_{2} \mathrm{O}+\mathrm{H}_{2} \mathrm{O} \\
& \mathrm{NH}_{2}+\mathrm{NO}_{2} \rightleftharpoons \mathrm{H}_{2} \mathrm{NO}+\mathrm{NO}
\end{aligned}
$$

have been discussed in detail in recent work by Klippenstein and coworkers $[38,51]$. We have adopted their values without modifications. For $\mathrm{NH}_{2}+\mathrm{NO}_{2}$, formation of the adducts $\mathrm{H}_{2} \mathrm{NNO}_{2}$ and $\mathrm{H}_{2}-$ NONO is pressure dependent, but Klippenstein et al. predict little effect of pressure below $100 \mathrm{~atm}$ because the complex lifetimes are too short to permit significant collisional relaxation [51].

Nitroxide may be formed in significant quantities from reaction of $\mathrm{NH}_{2}$ with $\mathrm{HO}_{2}$ and $\mathrm{NO}_{2}$. The $\mathrm{H}_{2} \mathrm{NO}$ subset of the reaction mechanism consists largely of reactions with estimated rate constants. While the most important reaction of $\mathrm{H}_{2} \mathrm{NO}$ is that with $\mathrm{O}_{2}$, discussed above, also the reactions with $\mathrm{HO}_{2}$ (R28) and $\mathrm{NH}_{2}$ (R30) are important consumption steps. The value of $\mathrm{k}_{28}$ is a rough estimate [36] and $\mathrm{k}_{30}$ was derived from QRRK calculations [33]. Similarly to $\mathrm{H}_{2} \mathrm{NO}$, HNO is mostly consumed by reaction with $\mathrm{O}_{2}$ (R32); also for this step we use a rate constant based on QRRK theory [33].

\section{Results and discussion}

Experiments for $\mathrm{NH}_{3}$ oxidation with high dilution in $\mathrm{N}_{2}$ as a function of temperature from $450 \mathrm{~K}$ to $900 \mathrm{~K}$ were conducted under stoichiometric and oxidizing conditions. Table 2 lists the experimental conditions. The fuel-air equivalence ratio, defined from the overall reaction $\mathrm{NH}_{3}+1.25 \mathrm{O}_{2} \rightarrow \mathrm{NO}+1.5 \mathrm{H}_{2} \mathrm{O}$, ranged from approximately 1.0 to 0.02 . Simulations with the full temperature profile were conducted using the CHEMKIN PRO software package [69]. Calculations restricted to the isothermal zone of the reactor showed similar trends, but with a smaller conversion at the highest temperatures (oxidizing conditions). The experimental results are compared with modeling predictions in Figs. 4-7. Symbols denote the experimental data and lines denote numerical results.

Figs. 4 and 5 show results for $\mathrm{NH}_{3}$ oxidation under stoichiometric conditions and pressures of 30 and 100 bar, respectively. At 30 bar the onset of reaction occurs at $800 \mathrm{~K}$. However, even above this temperature consumption of $\mathrm{NH}_{3}$ is very slow; at $925 \mathrm{~K}$ $730 \mathrm{ppm} \mathrm{NH}_{3}$ (95\% of the inlet concentration) and about $900 \mathrm{ppm} \mathrm{O}_{2}$ (97\% of the inlet concentration) are still unreacted in the reactor outlet. At 100 bar, $\mathrm{NH}_{3}$ consumption also starts around $800 \mathrm{~K}$, but as the temperature increases oxidation is slightly faster than at 30 bar. This can partly be attributed to a longer residence time. However, at $900 \mathrm{~K}$ still 675 ppm $\mathrm{NH}_{3}$ (i.e., 95\% of the inlet) remains unreacted.

The modeling results for stoichiometric conditions at 30 bar and 100 bar show very little reaction. The agreement with experiment can be considered satisfactory, since the measurements show that only around $40 \mathrm{ppm}$ or about $5 \%$ of $\mathrm{NH}_{3}$ are consumed at the highest temperatures at the two pressures.

Fig. 6 shows the results for $\mathrm{NH}_{3}$ oxidation at 30 bar for fuel-lean conditions. To investigate the impact of surface effects, these experiments were conducted in both an alumina and a quartz tube. Ammonia is known to decompose on quartz surfaces [70-72], and while surface effects are unimportant in SNCR for experiments carried out at low surface-to-volume ratios [36,73], it has been observed that induction times for oxidation of $\mathrm{NH}_{3}$ in quartz reactors were influenced by heterogeneous effects [28].

In the figure, the closed symbols indicate experimental results obtained in the quartz tube, while the open symbols denote results from the alumina tube. In the quartz tube, the onset temperature for reaction occurs at $850 \mathrm{~K}$, compared to a value of $875 \mathrm{~K}$ observed in the alumina tube. The difference can partly be attributed to the longer residence time in the quartz reactor, but it cannot be ruled out that some surface initiation takes place in the quartz reactor, despite the high pressure.

Upon initiation, $\mathrm{NH}_{3}$ is oxidized to $\mathrm{N}_{2}$ (not quantified) and $\mathrm{N}_{2} \mathrm{O}$; the concentrations of $\mathrm{NO}$ and $\mathrm{NO}_{2}$ in the product gas were below detection limit. Nitrous oxide is formed in significant amounts, reaching $50 \mathrm{ppm}$ in the alumina reactor and levels above $100 \mathrm{ppm}$ in the quartz reactor at $900 \mathrm{~K}$.

At 100 bar (Fig. 7), reaction is initiated already at $800-825 \mathrm{~K}$, partly due to the longer residence time, and $\mathrm{NH}_{3}$ is fully oxidized at $875-900 \mathrm{~K}$. The $\mathrm{N}_{2} \mathrm{O}$ concentration approaches $200 \mathrm{ppm}$, corresponding to a selectivity for forming $\mathrm{N}_{2} \mathrm{O}$ from $\mathrm{NH}_{3}$ of about $50 \%$. The $\mathrm{N}_{2} \mathrm{O}$ profiles from the quartz and alumina reactors indicate a difference in onset temperature, but the peak concentrations are

\begin{tabular}{|c|c|c|c|c|c|}
\hline Experiment & Inlet composition $^{\mathrm{a}}$ & Pressure (bar) & Temperature (K) & Residence time $^{\mathrm{b}}(\mathrm{s})$ & Reactor \\
\hline 1 & $772 \mathrm{ppm} \mathrm{NH} 3,929 \mathrm{ppm} \mathrm{O}_{2}(\phi=1.04)$ & 30 & $450-925$ & $3100 / \mathrm{T}[\mathrm{K}]$ & Quartz \\
\hline 2 & $714 \mathrm{ppm} \mathrm{NH} \mathrm{NH}_{3}, 864 \mathrm{ppm} \mathrm{O}_{2}(\phi=1.03)$ & 100 & $450-925$ & $10,330 / \mathrm{T}[\mathrm{K}]$ & Quartz \\
\hline 3 & $729 \mathrm{ppm} \mathrm{NH}, 3.95 \%(\mathrm{v}) \mathrm{O}_{2}(\phi=0.23)$ & 30 & $450-925$ & $3100 / \mathrm{T}[\mathrm{K}]$ & Quartz \\
\hline 4 & $719 \mathrm{ppm} \mathrm{NH} \mathrm{NH}_{3}, 4.03 \%(\mathrm{v}) \mathrm{O}_{2}(\phi=0.22)$ & 30 & $450-925$ & $1984 / \mathrm{T}[\mathrm{K}]$ & Alumina \\
\hline 5 & $789 \mathrm{ppm} \mathrm{NH} 3,4.07 \%(\mathrm{v}) \mathrm{O}_{2}(\phi=0.24)$ & 100 & $450-925$ & $10,330 / \mathrm{T}[\mathrm{K}]$ & Quartz \\
\hline 6 & $789 \mathrm{ppm} \mathrm{NH}, 4.07 \%(\mathrm{v}) \mathrm{O}_{2}(\phi=0.24)$ & 100 & $450-925$ & $6610 / \mathrm{T}[\mathrm{K}]$ & Alumina \\
\hline
\end{tabular}
similar.

Table 2

Experimental conditions for the $\mathrm{NH}_{3}$ oxidation study.

a Volume basis; balance $\mathrm{N}_{2}$.

b The nominal residence time in the isothermal region of the reactor. It is a function of temperature, since the mass flow rate was held constant. 


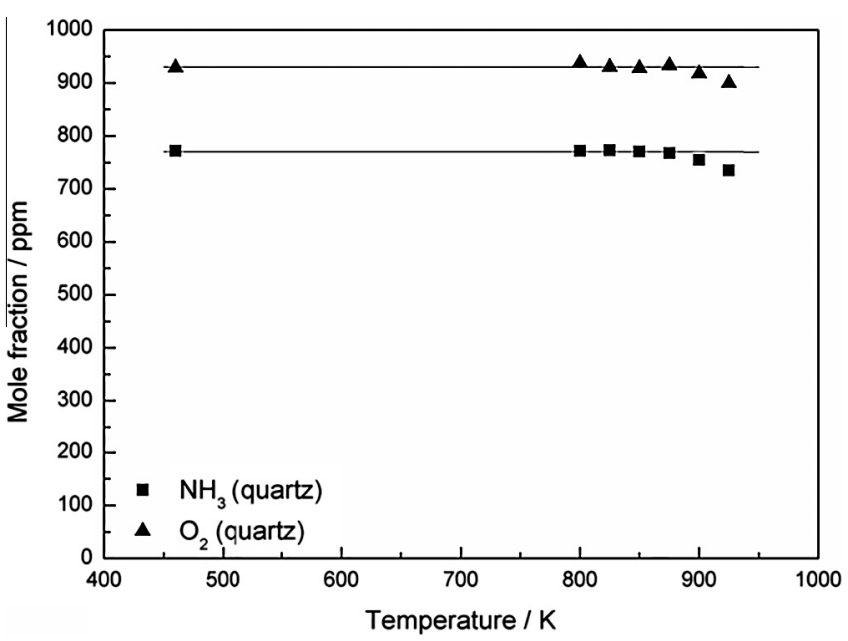

Fig. 4. Comparison of experimental and predicted concentration profiles as a function of the reactor temperature for the stoichiometric experiment at $30 \mathrm{bar}$ in the quartz reactor. The symbols mark experimental data while solid lines denote model predictions obtained at isothermal conditions. Inlet composition: $772 \mathrm{ppm}$ $\mathrm{NH}_{3}, 929 \mathrm{ppm} \mathrm{O}_{2}$; balance $\mathrm{N}_{2}$. The fuel-air equivalence ratio is $\phi=1.04$ and the residence time in the isothermal zone is calculated from $\tau[\mathrm{s}]=3100 / \mathrm{T}[\mathrm{K}]$.

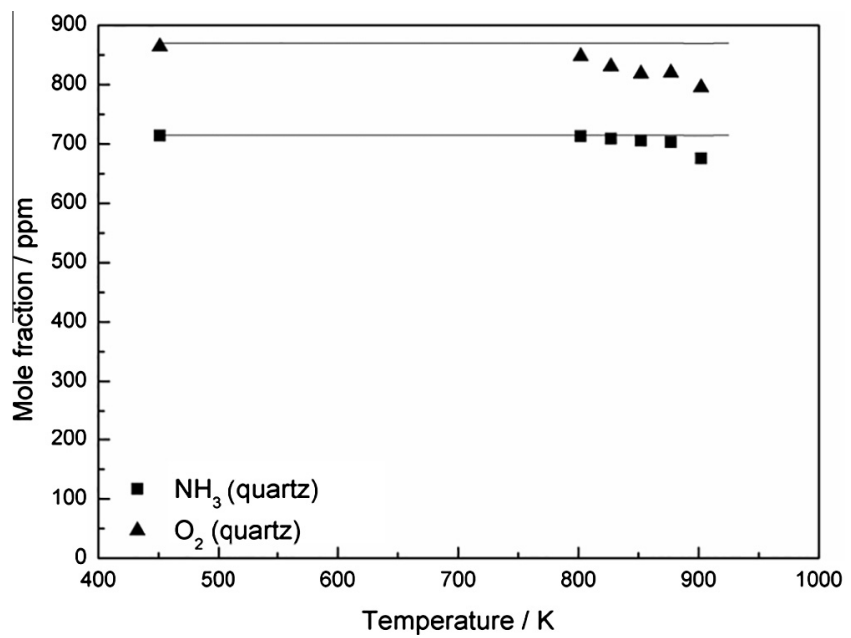

Fig. 5. Comparison of experimental and predicted concentration profiles as a function of the reactor temperature for the stoichiometric experiment at 100 bar in the quartz reactor. The symbols mark experimental data while solid lines denote model predictions obtained at isothermal conditions. Inlet composition: $714 \mathrm{ppm}$ $\mathrm{NH}_{3}, 864 \mathrm{ppm} \mathrm{O}_{2}$; balance $\mathrm{N}_{2}$. The fuel-air equivalence ratio is $\phi=1.03$ and the residence time in the isothermal zone is calculated from $\tau[\mathrm{s}]=10,330 / \mathrm{T}[\mathrm{K}]$.

The model satisfactorily predicts the experimental data. The best agreement is obtained for the alumina reactor data, which are possibly more reliable. At 30 bar, the agreement is very good, while at 100 bar the temperature for onset of reaction is slightly overpredicted. The most important difference is that the concentration of $\mathrm{N}_{2} \mathrm{O}$ is underpredicted at the highest pressure. In line with observations, the model predicts that any $\mathrm{NO}$ or $\mathrm{NO}_{2}$ formed are rapidly consumed.

Fig. 8 shows the results of a rate of production analysis under oxidizing conditions. The arrow thickness distinguishes the main and minor routes for ammonia consumption. Results are shown for 100 bar conditions, but the reaction paths are similar for 30 bar. The main oxidation for ammonia is $\mathrm{NH}_{3} \stackrel{+\mathrm{OH}}{\longrightarrow} \mathrm{NH}_{2}$ $\stackrel{+\mathrm{HO}_{2}, \mathrm{NO}_{2}}{\longrightarrow} \mathrm{H}_{2} \mathrm{NO} \stackrel{+\mathrm{O}_{2}}{\longrightarrow} \mathrm{HNO} \stackrel{+\mathrm{O}_{2}}{\longrightarrow} \mathrm{NO} \stackrel{+\mathrm{NH}_{2}}{\longrightarrow} \mathrm{N}_{2}$. Ammonia is mainly consumed through the reaction $\mathrm{NH}_{3}+\mathrm{OH}=\mathrm{NH}_{2}+\mathrm{H}_{2} \mathrm{O}$ (R4). The

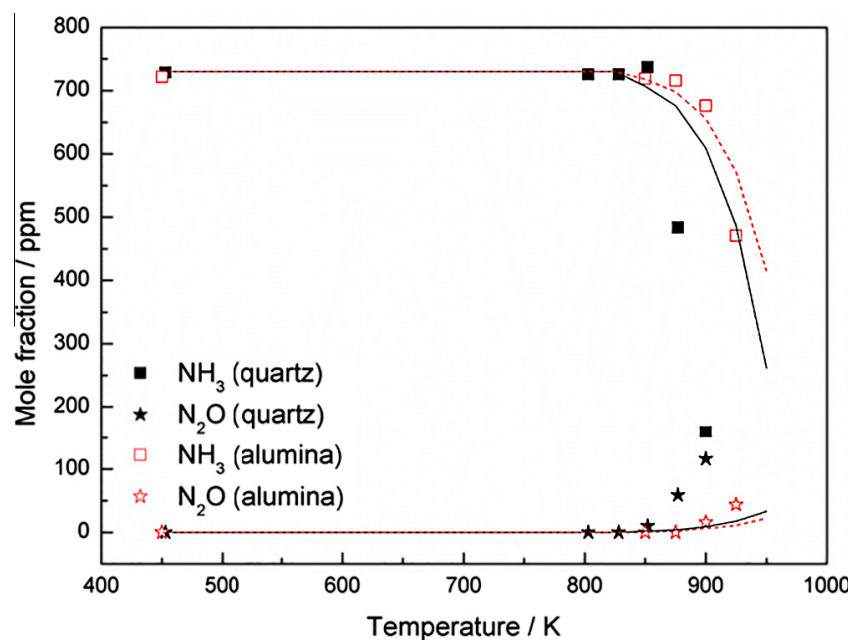

Fig. 6. Comparison of experimental and predicted concentration profiles as a function of the reactor temperature for the oxidizing experiment at $30 \mathrm{bar}$, obtained in a quartz and alumina tube, respectively. The symbols mark experimental data while solid lines denote model predictions obtained at isothermal conditions. Inlet composition: $729 \mathrm{ppm} \mathrm{NH}_{3}, 3.95 \%(\mathrm{v}) \mathrm{O}_{2}$; balance $\mathrm{N}_{2}$. The fuel-air equivalence ratio is $\phi=0.023$ and the residence time in the isothermal zone is calculated from $\tau[\mathrm{s}]$ $=3100 / \mathrm{T}[\mathrm{K}]$ for the quartz tube and $\tau[\mathrm{s}]=1984 / \mathrm{T}[\mathrm{K}]$ for the alumina tube.

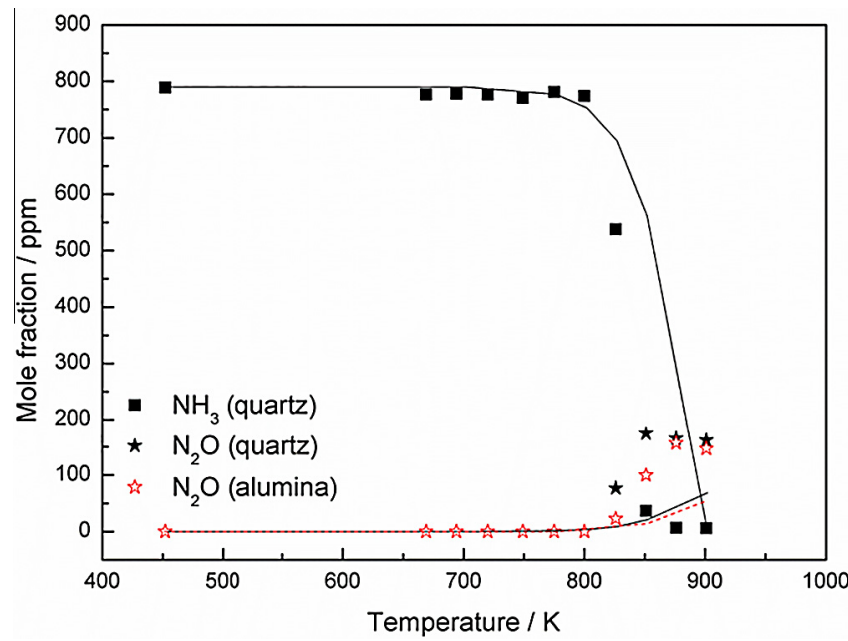

Fig. 7. Comparison of experimental and predicted concentration profiles as a function of the reactor temperature for the oxidizing experiment at $100 \mathrm{bar}$ obtained in a quartz and alumina tube, respectively. The symbols mark experimental data while solid lines denote model predictions obtained at isothermal conditions. Inlet composition: $789 \mathrm{ppm} \mathrm{NH}_{3}, 4.07 \%(\mathrm{v}) \mathrm{O}_{2}$; balance $\mathrm{N}_{2}$. The fuel-air equivalence ratio is $\phi=0.024$ and the residence time in the isothermal zone is calculated from $\tau[\mathrm{s}]=10,330 / \mathrm{T}[\mathrm{K}]$ for the quartz tube and $\tau[\mathrm{s}]=6610 / \mathrm{T}[\mathrm{K}]$ for the alumina tube.

peroxide radical $\mathrm{HO}_{2}$ is the main chain carrier under the present conditions with high pressure and low to intermediate temperatures. However, $\mathrm{HO}_{2}$ is partly converted to $\mathrm{OH}$ through the fast steps,

$\mathrm{NO}+\mathrm{HO}_{2} \rightleftharpoons \mathrm{NO}_{2}+\mathrm{OH}$

$\mathrm{NH}_{2}+\mathrm{HO}_{2} \rightleftharpoons \mathrm{H}_{2} \mathrm{NO}+\mathrm{OH}$

In addition to (R11), the $\mathrm{NH}_{2}$ radical reacts mainly with $\mathrm{NO}_{2}$,

$\mathrm{NH}_{2}+\mathrm{NO}_{2} \rightleftharpoons \mathrm{N}_{2} \mathrm{O}+\mathrm{H}_{2} \mathrm{O}$

$\mathrm{NH}_{2}+\mathrm{NO}_{2} \rightleftharpoons \mathrm{H}_{2} \mathrm{NO}+\mathrm{NO}$ 


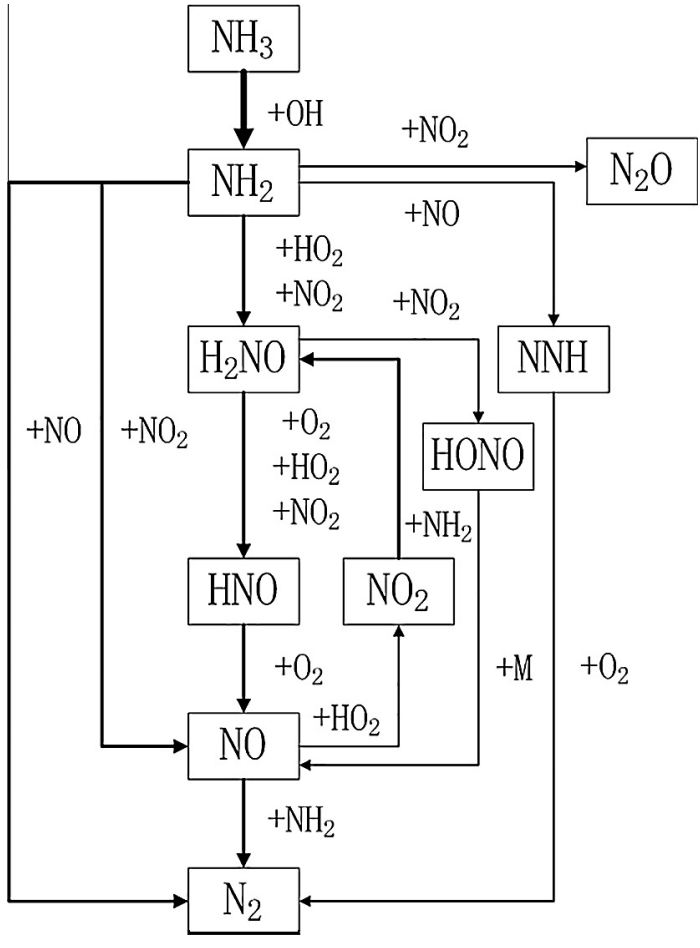

Fig. 8. Main reaction pathways for $\mathrm{NH}_{3}$ oxidation at the investigated conditions. The diagram is based on the 100 bar oxidizing condition at a temperature of $875 \mathrm{~K}$, but reaction paths are similar at 30 bar oxidizing conditions.

Most of the $\mathrm{NH}_{2}$ is converted to $\mathrm{H}_{2} \mathrm{NO}$ (R11, R21). Nitroxide then reacts with $\mathrm{O}_{2}$ (R29), $\mathrm{HO}_{2}$ (R28), and $\mathrm{NO}_{2}$ (R31); these steps all abstract a hydrogen atom from $\mathrm{H}_{2} \mathrm{NO}$ to form $\mathrm{HNO}$, which is converted to NO by reaction with $\mathrm{O}_{2}$ (R32).

$\mathrm{H}_{2} \mathrm{NO}+\mathrm{O}_{2} \rightleftharpoons \mathrm{HNO}+\mathrm{HO}_{2}$

$\mathrm{H}_{2} \mathrm{NO}+\mathrm{HO}_{2} \rightleftharpoons \mathrm{HNO}+\mathrm{H}_{2} \mathrm{O}_{2}$

$\mathrm{H}_{2} \mathrm{NO}+\mathrm{NO}_{2} \rightleftharpoons \mathrm{HNO}+\mathrm{HONO}$

$\mathrm{HNO}+\mathrm{O}_{2} \rightleftharpoons \mathrm{NO}+\mathrm{HO}_{2}$

Finally, $\mathrm{NO}$ reacts with $\mathrm{HO}_{2}$ or $\mathrm{NH}_{2}$. The $\mathrm{NH}_{2}+\mathrm{NO}$ reaction leads to formation of $\mathrm{N}_{2}$, either directly

$\mathrm{NH}_{2}+\mathrm{NO} \rightleftharpoons \mathrm{N}_{2}+\mathrm{H}_{2} \mathrm{O}$

or via

$\mathrm{NH}_{2}+\mathrm{NO} \rightleftharpoons \mathrm{NNH}+\mathrm{OH}$

followed by rapid dissociation of $\mathrm{NNH}$ (R33) or reaction with $\mathrm{O}_{2}$ (R34).

The reaction $\mathrm{NH}_{2}+\mathrm{NO}_{2}=\mathrm{N}_{2} \mathrm{O}+\mathrm{H}_{2} \mathrm{O}(\mathrm{R} 20)$ is the main source of $\mathrm{N}_{2} \mathrm{O}$ at both 30 bar and 100 bar oxidizing conditions. A minor route for consumption of $\mathrm{NH}_{2}$ is the recombination reaction to form hydrazine,

$\mathrm{NH}_{2}+\mathrm{NH}_{2}(+\mathrm{M}) \rightleftharpoons \mathrm{N}_{2} \mathrm{H}_{4}(+\mathrm{M})$

Fig. 9 shows the results of a sensitivity analysis for oxidizing conditions at 30 and 100 bar. The coefficients were obtained by varying A-factors for all reactions by a factor of two. Reactions of $\mathrm{NH}_{2}$ with $\mathrm{NO}$ and $\mathrm{NO}_{2}$ are important for the oxidation rate. For both reactions a chain propagating/branching product channel,

$\mathrm{NH}_{2}+\mathrm{NO} \rightleftharpoons \mathrm{NNH}+\mathrm{OH}$

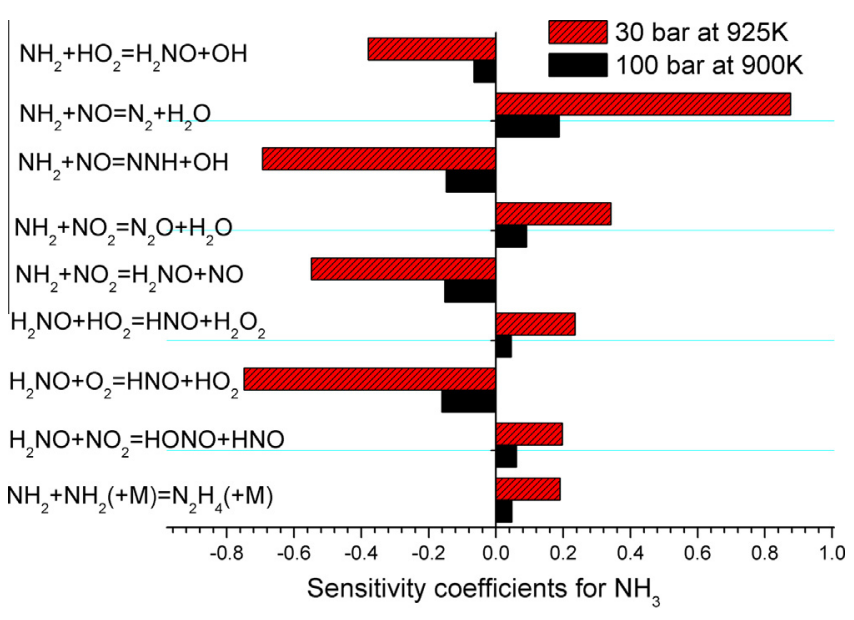

Fig. 9. First order sensitivity coefficients for $\mathrm{NH}_{3}$ for conditions of 30 bar ( $925 \mathrm{~K}$ ) and 100 bar $(900 \mathrm{~K})$.

$\mathrm{NH}_{2}+\mathrm{NO}_{2} \rightleftharpoons \mathrm{H}_{2} \mathrm{NO}+\mathrm{NO}$

competes with a chain terminating channel,

$\mathrm{NH}_{2}+\mathrm{NO} \rightleftharpoons \mathrm{N}_{2}+\mathrm{H}_{2} \mathrm{O}$

$\mathrm{NH}_{2}+\mathrm{NO}_{2} \rightleftharpoons \mathrm{N}_{2} \mathrm{O}+\mathrm{H}_{2} \mathrm{O}$

All these steps show up in the sensitivity analysis with large positive (branching) or negative (terminating) coefficients.

Other important reactions which accelerate ammonia consumption are,

$\mathrm{NH}_{2}+\mathrm{HO}_{2} \rightleftharpoons \mathrm{H}_{2} \mathrm{NO}+\mathrm{OH}$

$\mathrm{H}_{2} \mathrm{NO}+\mathrm{O}_{2} \rightleftharpoons \mathrm{HNO}+\mathrm{HO}_{2}$

The reaction $\mathrm{H}_{2} \mathrm{NO}+\mathrm{O}_{2}$ (R29) has the largest positive sensitivity coefficients. $\mathrm{H}_{2} \mathrm{NO}$ is a significant intermediate species as shown in the reaction path analysis and (R29) is favored by the excess of $\mathrm{O}_{2}$ in oxidizing conditions. It yields $\mathrm{HO}_{2}$ radicals, which is converted to the more reactive $\mathrm{OH}$ radical by $\mathrm{NH}_{2}+\mathrm{HO}_{2}$ (R11).

The following chain terminating steps inhibit the ammonia consumption,

$\mathrm{H}_{2} \mathrm{NO}+\mathrm{HO}_{2} \rightleftharpoons \mathrm{HNO}+\mathrm{H}_{2} \mathrm{O}_{2}$

$\mathrm{H}_{2} \mathrm{NO}+\mathrm{NO}_{2} \rightleftharpoons \mathrm{HONO}+\mathrm{HNO}$

$\mathrm{NH}_{2}+\mathrm{NH}_{2}(+\mathrm{M}) \rightleftharpoons \mathrm{N}_{2} \mathrm{H}_{4}(+\mathrm{M})$

Reactions (R28) and (R31) are minor consumption channels for $\mathrm{H}_{2} \mathrm{NO}$, compared to $\mathrm{H}_{2} \mathrm{NO}+\mathrm{O}_{2}$ (R29), but sufficiently important to show up in the sensitivity analysis. Similarly, $\mathrm{NH}_{2}+\mathrm{NH}_{2}(+\mathrm{M})$ is a minor sink for $\mathrm{NH}_{2}$, but it is strongly chain terminating.

The results show that to develop a reliable reaction mechanism for $\mathrm{NH}_{3}$ oxidation at the present conditions, it is desirable to obtain more accurate rate constants for several reactions in the $\mathrm{H}_{2} \mathrm{NO}$ subset.

\section{Conclusions}

Ammonia oxidation experiments were conducted at high pressure ( 30 bar and 100 bar) and temperatures of $450-900 \mathrm{~K}$ in oxidizing and stoichiometric conditions. The data were interpreted in terms of a detailed chemical kinetic model, developed for high-pressure conditions. As part of the work, the rate constant for the reaction of $\mathrm{H}_{2} \mathrm{NO}+\mathrm{O}_{2}$ was calculated from ab initio theory. 
The oxidation of ammonia was slow under stoichiometric conditions in the temperature range investigated. Under oxidizing conditions the onset temperature for reaction was $850-875 \mathrm{~K}$ at 30 bar, while at 100 bar it was about $800 \mathrm{~K}$, with complete consumption of $\mathrm{NH}_{3}$ at $875 \mathrm{~K}$. The products of reaction were $\mathrm{N}_{2}$ and $\mathrm{N}_{2} \mathrm{O}$, while $\mathrm{NO}$ and $\mathrm{NO}_{2}$ concentrations were below the detection limit even under oxidizing conditions.

The agreement between experimental results and modeling work was satisfactory. The main oxidation path for $\mathrm{NH}_{3}$ under the present conditions was $\mathrm{NH}_{3} \stackrel{+\mathrm{OH}}{\longrightarrow} \mathrm{NH}_{2} \stackrel{+\mathrm{HO}_{2}, \mathrm{NO}_{2}}{\longrightarrow} \mathrm{H}_{2}$ $\mathrm{NO} \stackrel{+\mathrm{O}_{2}}{\longrightarrow} \mathrm{HNO} \stackrel{+\mathrm{O}_{2}}{\longrightarrow} \mathrm{NO} \stackrel{+\mathrm{NH}_{2}}{\longrightarrow} \mathrm{N}_{2}$. The modeling predictions were most sensitive to the reactions $\mathrm{NH}_{2}+\mathrm{NO}=\mathrm{NNH}+\mathrm{OH}$ and $\mathrm{NH}_{2}+\mathrm{HO}_{2}=$ $\mathrm{H}_{2} \mathrm{NO}+\mathrm{OH}$, which promoted the ammonia consumption by forming $\mathrm{OH}$ radicals, and to $\mathrm{NH}_{2}+\mathrm{NO}=\mathrm{N}_{2}+\mathrm{H}_{2} \mathrm{O}$ and $\mathrm{NH}_{2}+\mathrm{NO}_{2}=$ $\mathrm{N}_{2} \mathrm{O}+\mathrm{H}_{2} \mathrm{O}$, which were the main chain-terminating steps.

\section{Acknowledgments}

The work is part of the CHEC (Combustion and Harmful Emission Control) research program at DTU Chemical Engineering. YS wishes to acknowledge funding from CSC (China Scholarship Council). PM thanks the R.A. Welch Foundation (Grant B-1174) for support.

\section{Appendix A. Supplementary material}

Supplementary data associated with this article can be found, in the online version, at http://dx.doi.org/10.1016/j.fuel.2016.04.100.

\section{References}

[1] Glarborg P, Jensen AD, Johnsson JE. Fuel nitrogen conversion in solid fuel fired systems. Prog Energy Combust Sci 2003;29:89-113.

[2] Hasegawa T, Sato M. Study of ammonia removal from coal-gasified fuel. Combust Flame 1998;114:246-58.

[3] Miller JA, Bowman CT. Mechanism and modeling of nitrogen chemistry in combustion. Prog Energy Combust Sci 1989;15:287-338.

[4] Lyon RK. Kinetics and mechanism of thermal DeNOx: a review. In: 194th annu ACS meet; div fuel chem, vol. 32; 1987. p. 433.

[5] Duynslaegher C, Jeanmart H, Vandooren J. Kinetics in ammonia-containing premixed flames and a preliminary investigation of their use as fuel in spark ignition engines. Combust Sci Technol 2009;181:1092-106.

[6] Fenimore CP, Jones GW. Oxidation of ammonia in flames. J Phys Chem 1961;65:298-303.

[7] MacLean DI, Wagner HGg. The structure of the reaction zones of ammoniaoxygen and hydrazine decomposition flames. Proc Combust Inst 1967;11:871-8.

[8] Blint RJ, Dasch CJ. Formation of $\mathrm{NO}$ and $\mathrm{N}_{2}$ from $\mathrm{NH}_{3}$ in flames. In: ACS symp ser, vol. 249; 1984. p. 87-101.

[9] Dasch CJ, Blint RJ. A mechanistic and experimental study of ammonia flames. Combust Sci Technol 1984:41:223-44.

[10] Dean AM, Chou M-S, Stern D. Nitrogen chemistry in flames. Observations and detailed chemistry. In: ACS symp ser, vol. 249; 1984. p. 71-86.

[11] Dean AM, Chou M-S, Stern D. Kinetics of rich ammonia flames. Int J Chem Kinet 1984;16:633-53.

[12] Zabielsky MF, Seery DJ. High temperature measurements of the rate of the reaction of $\mathrm{OH}$ with $\mathrm{NH}_{3}$. Int J Chem Kinet 1991;17:1191-9.

[13] Bian J, Vandooren J, Van Tiggelen PJ. Experimental study of the structure of an ammonia-oxygen flame. Proc Combust Inst 1988;21:953-63.

[14] Sausa RC, Singh G, Lemire GW, Anderson WR. Molecular beam mass spectrometric and modeling studies of neat and $\mathrm{NH}_{3}$-doped low-pressure $\mathrm{H}_{2} / \mathrm{N}_{2} \mathrm{O} / \mathrm{Ar}$ flames: formation and consumption of NO. Proc Combust Inst 1996;26:1043-52.

[15] Hayakawa A, Goto T, Mimoto R, Arakawa Y, Kudo T, Kobayashi H. Laminar burning velocity and Markstein length of ammonia/air premixed flames at various pressures. Fuel 2015;159:98-106.

[16] Brackmann C, Alekseev VA, Zhou B, Nordstrom E, Bengtsson P-E, Li Z, et al. Structure of premixed ammonia + air flames at atmospheric pressure: laser diagnostics and kinetic modeling. Combust Flame 2016;163:370-81.

[17] Takeyama T, Miyama H. Kinetic studies of ammonia oxidation in shock waves. I. The reaction mechanism for the induction period. Bull Chem Soc Jpn 1965;38:1670-4.

[18] Takeyama T, Miyama H. Kinetic studies of ammonia oxidation in shock waves. II. The rate of ammonia consumption. Bull Chem Soc Jpn 1966;39:2352-5.
[19] Takeyama T, Miyama H. A shock-tube study of the ammonia-oxygen reaction. Proc Combust Inst 1967:11:845-52.

[20] Bull DC. A shock tube study of the oxidation of ammonia. Combust Flame 1968;12:603-10.

[21] Miyama $\mathrm{H}$. Kinetic studies of ammonia oxidation in shock waves. IV. Comparison of induction periods for the ignition of $\mathrm{NH}_{3}-\mathrm{O}_{2}-\mathrm{N}_{2}$ with those for $\mathrm{NH}_{3}-\mathrm{O}_{2}-\mathrm{Ar}$ mixtures. Bull Chem Soc Jpn 1968;41:1761-5.

[22] Miyama H. Ignition of ammonia-oxygen mixtures by shock waves. J Chem Phys 1968:48:1421-2.

[23] Bradley JN, Butlin RN, Lewis D. Oxidation of ammonia in shock waves. Trans Faraday Soc 1968;64:71-8.

[24] Drummond LJ. High temperature oxidation of ammonia. Combust Sci Technol 1972;5:175-82.

[25] Fujii N, Miyama H, Koshi M, Asaba T. Kinetics of ammonia oxidation in shock waves. Proc Combust Inst 1981;18:873-83.

[26] Salimian S, Hanson RK, Kruger $\mathrm{CH}$. Ammonia oxidation in shock-heated $\mathrm{NH}_{3}-$ $\mathrm{N}_{2} \mathrm{O}-\mathrm{Ar}$ mixtures. Combust Flame 1984;56:83-95.

[27] Mathieu O, Petersen EL. Experimental and modeling study on the hightemperature oxidation of ammonia and related NOx chemistry. Combust Flame 2015;162:554-70.

[28] Dean AM, Hardy JE, Lyon RK. Kinetics and mechanism of $\mathrm{NH}_{3}$ oxidation. Proc Combust Inst 1982;19:97-105.

[29] Hulgaard T, Dam-Johansen K. Homogeneous nitrous oxide formation and destruction under combustion conditions. AIChE J 1993;39:1342-54.

[30] Wargadalam VJ, Loffler G, Winter F, Hofbauer H. Homogeneous formation of $\mathrm{NO}$ and $\mathrm{N}_{2} \mathrm{O}$ from the oxidation of $\mathrm{HCN}$ and $\mathrm{NH}_{3}$ at $600-1000{ }^{\circ} \mathrm{C}$. Combust Flame 2000;120:465-78.

[31] Miller JA, Smooke MD, Green RM, Kee RJ. Kinetic modeling of the oxidation of ammonia in flames. Combust Sci Technol 1983:34:149-76.

[32] Lindstedt RP, Lockwood FC, Selim MA. A detailed kinetic study of ammonia oxidation. Combust Sci Technol 1995;108:231-54.

[33] Dean AM, Bozzelli JW. Combustion chemistry of nitrogen. In: Gardiner WC, editor. Gas phase combustion chemistry. New York: Springer; 2000 [chapter 2].

[34] Skreiberg Ø, Kilpinen K, Glarborg P. Ammonia chemistry under fuel-rich conditions in a flow reactor. Combust Flame 2004;136:501-8.

[35] Duynslaegher C, Contino F, Vandooren J, Jeanmart H. Modeling of ammonia combustion at low pressure. Combust Flame 2012;159:2799-805.

[36] Glarborg P, Dam-Johansen K, Miller JA, Kee RJ, Coltrin ME. Modeling the thermal DENOx process in flow reactors. Surface effects and nitrous oxide formation. Int J Chem Kinet 1994;26:421-36.

[37] Miller JA, Glarborg P. Modeling the thermal De-NOx process: closing in on a final solution. Int J Chem Kinet 1999;31:757-65.

[38] Klippenstein SJ, Harding LB, Glarborg P, Miller JA. The role of NNH in NO formation and control. Combust Flame 2011;158:774-89.

[39] Grinberg Dana A, Tvil G, Winter L, Shter GE, Grader GS. Pressure effect on the combustion of aqueous urea ammonium nitrate alternative fuel. Fuel 2015:159:500-7.

[40] Mendiara T, Glarborg P. Ammonia chemistry in oxy-fuel combustion of methane. Combust Flame 2009;156:1937-49.

[41] Tian Z, Li Y, Zhang L, Glarborg P, Qi F. An experimental and kinetic modeling study of premixed $\mathrm{NH}_{3} / \mathrm{CH}_{4} / \mathrm{O}_{2} / \mathrm{Ar}$ flames at low pressure. Combust Flame 2009;156:1413-26.

[42] Rasmussen CL, Hansen J, Marshall P, Glarborg P. Experimental measurements and kinetic modeling of $\mathrm{CO} / \mathrm{H}_{2} / \mathrm{O}_{2} / \mathrm{NO}_{\mathrm{x}}$ conversion at high pressure. Int J Chem Kinet 2008;40:454-80.

43] Altinay G, Macdonald RG. Determination of the rate constants for the $\mathrm{NH}_{2}\left(\mathrm{X}^{2} \mathrm{~B}_{1}\right)+\mathrm{NH}_{2}\left(\mathrm{X}^{2} \mathrm{~B}_{1}\right)$ and $\mathrm{NH}_{2}\left(\mathrm{X}^{2} \mathrm{~B}_{1}\right)+\mathrm{H}$ recombination reactions in $\mathrm{N}_{2}$ as a function of temperature and pressure. J Phys Chem A 2015;119:7593-610.

[44] Michael JV, Sutherland JW, Klemm RB. Rate constant for the reaction $\mathrm{H}+\mathrm{NH}_{3}$ over the temperature range 750-1777 K. J Phys Chem 1986;90:497.

[45] Sutherland JW, Patterson PM, Klemm RB. Flash photolysis-shock tube kinetic investigation of the reaction of $\mathrm{O}(3 \mathrm{P})$ atoms with ammonia. J Phys Chem 1990;94:2471-5.

[46] Salimian S, Hanson RK, Kruger CH. High-temperature study of the reactions of $\mathrm{O}$ and $\mathrm{OH}$ with $\mathrm{NH}_{3}$. Int J Chem Kinet 1984;16:725.

[47] Sumathi R, Peyerimhoff SD. A quantum statistical analysis of the rate constan for the $\mathrm{HO}_{2}+\mathrm{NH}_{2}$ reaction. Chem Phys Lett 1996;263:742-8.

[48] Linder DP, Duan X, Page M. Ab initio variational transition state theory calculations for the $\mathrm{H}+\mathrm{NH}_{2}=\mathrm{H}_{2}+\mathrm{NH}$ hydrogen abstraction reaction on the triplet potential energy surface. J Phys Chem 1995;99:11458-63.

[49] Klippenstein SJ, Harding LB, Ruscic B, Sivaramakrishnan R, Srinivasan NK, Su $\mathrm{M}-\mathrm{C}$, et al. Thermal decomposition of $\mathrm{NH}_{2} \mathrm{OH}$ and subsequent reactions: ab initio transition state theory and reflected shock tube experiments. J Phys Chem A 2009;113:10241-59.

[50] Mebel AM, Diau EWG, Lin MC, Morokuma K. Theoretical rate constants for the $\mathrm{NH}_{3}+\mathrm{NO}_{\mathrm{x}} \rightarrow \mathrm{NH}_{2}+\mathrm{HNO}_{\mathrm{x}}(\mathrm{x}=1,2)$ reactions by ab initio MO/VTST calculations. J Phys Chem 1996;100:7517-25.

[51] Klippenstein SJ, Harding LB, Glarborg P, Gao Y, Marshall P. Rate constant and branching fraction for the $\mathrm{NH}_{2}+\mathrm{NO}_{2}$ reaction. J Phys Chem $\mathrm{A}$ 2013;117:9011-22.

[52] Sun F, DeSain JD, Scott G, Hung PY, Thompson RI, Glass GP, et al. Reactions of $\mathrm{NH}_{2}$ with $\mathrm{NO}_{2}$ and of $\mathrm{OH}$ with $\mathrm{NH}_{2} \mathrm{O}$. J Phys Chem A 2001;105:6121-8.

[53] Glarborg P, Dam-Johansen K, Miller JA. The reaction of ammonia with nitrogen dioxide in a flow reactor: implications for the $\mathrm{NH}_{2}+\mathrm{NO}_{2}$ reaction. Int J Chem Kinet 1995;27:1207-20. 
[54] Johnson III RD. Computational chemistry comparison and benchmark database. Version 17b. National Institute of Standards and Technology. <http://cccbdb.nist.gov> [accessed October, 2015].

[55] Frisch MJ, Trucks GW, Schlegel HB, Scuseria GE, Robb MA, Cheeseman JR, et al Gaussian 09. Wallingford (CT): Gaussian; 2009.

[56] Werner H-J, Knowles PJ, Knizia G, Manby FR, Schutz M, Celani P, et al. MOLPRO. Version 2010.1; 2010. <http://www.molpro.net>.

[57] Barker JR, Ortiz NF, Preses JM, Lohr LL, Maranzana A, Stimac PJ, et al. MultiWell-2014.1. Ann Arbor (MI): University of Michigan; 2014. <http://aossresearch.engin.umich.edu/multiwell/>.

[58] Mikami H, Saito S, Yamamoto S. The microwave-spectrum of the dihydronitrosyl radical, $\mathrm{H}_{2} \mathrm{NO}$ (2B1). I Chem Phys 1991:94:3415-22.

[59] Dixon DA, Francisco JS, Alexeev Y. Thermochemical properties of $\mathrm{H}_{\mathrm{X}} \mathrm{NO}$ molecules and ions from ab initio electronic structure theory. J Phys Chem A 2006;110:185.

[60] Herzberg G. Infrared and Raman spectra of polyatomic molecules, vol. 2. New York: D. Van Nostrand; 1945. p. 632.

[61] Johnson III RD; 1999. <http://www.nist.gov/mml/csd/informatics research/fourier grid hamiltonian interface.cfm>.

[62] Ruscic B, Active thermochemical tables. Version 1.112. Argonne National Laboratory. <http://atct.anl.gov> [accessed October, 2015].

[63] Pouchan C, Lam B, Bishop DM. A theoretical study of the reaction between $\mathrm{NH}_{2}$ and $\mathrm{HO}_{2}$. J Phys Chem 1987;91:4809-13.
[64] Bozzelli JW, Dean AM. Energized complex quantum Rice-Ramsberger-Kassel analysis on reactions of $\mathrm{NH}_{2}$ with $\mathrm{HO}_{2}, \mathrm{O}_{2}$ and $\mathrm{O}$ atoms. J Phys Chem 1989;93:1058-65.

[65] Xiang TC, Si HY, Han PL, Ruan Y. Theoretical study on the mechanism of the $\mathrm{HO}_{2}$ plus $\mathrm{NH}_{2}$ reaction. Comput Theor Chem 2012;985:67-71.

[66] Cheskis SG, Sarkisov OM. Flash photolysis of ammonia in the presence of oxygen. Chem Phys Lett 1979;62:72.

[67] Lozovskii VA, Nadtochenko VA, Sarkisov OM, Cheskis SG. Study of $\mathrm{NH}_{2}$ radical recombination by intraresonator laser spectroscopy. Kinet Catal 1979;20:918-22.

[68] Lesclaux R. Reactivity and kinetic properties of the $\mathrm{NH}_{2}$ radical in the gasphase. Rev Chem Intermed 1984;5:347.

[69] CHEMKIN PRO version 15131. Reaction Design, San Diego, USA; 2013.

[70] Hinshelwood CN, Burk RE. The thermal decomposition of ammonia upon various surfaces. J Chem Soc 1925;127:1105-17.

[71] Roenigk KF, Jensen KF. Low pressure CVD of silicon nitride. J Electrochem Soc $1987 ; 134: 1777-85$.

[72] Cooper DA, Ljungstrom EB. Decomposition of $\mathrm{NH}_{3}$ over quartz sand at 840$960{ }^{\circ} \mathrm{C}$. Energy Fuels 1988;2:716-9.

[73] Suhlmann J, Rotzoll G. The influence of quartz glass surfaces on the reduction of $\mathrm{NO}$ with $\mathrm{NH}_{3}$ at high temperatures. Chem Ing Techn 1992;64:580-1. 